\title{
Piecing Together the Puzzle of Adherence in Sleep Medicine
}

Editor

JESSIE P. BAKKER

\section{SLEEP MEDICINE CLINICS}

www.sleep.theclinics.com

Consulting Editor

TEOFILO LEE-CHIONG Jr

March 2021 • Volume 16 - Number 1 